\title{
Factors influencing poor academic performance among urban university students in Bangladesh
}

\author{
M. Shahjahan', Kazi Rumana Ahmed², Ahmed Al Hadrami', Md. Rabiul Islam ${ }^{4}$, Sharmin Hossain ${ }^{5}$, \\ Md. Sabur Khan ${ }^{6}$ \\ ${ }^{1}$ Department of Public Health, Daffodil International University (DIU), Bangladesh \\ ${ }^{2,5}$ Department of Health Promotion \& Health Education, Bangladesh University of Health Sciences, Bangladesh \\ ${ }^{2}$ School of Health \& Rehabilitation Sciences, The University of Queensland, Brisbane, Australia \\ ${ }^{3}$ Department of Statistics, Sultan Qaboos University, Muscat, Oman \\ ${ }^{4}$ Department of Public Health, School of Pharmacy and Public Health, Independent University, Bangladesh \\ ${ }^{6}$ Daffodil International University (DIU), Bangladesh
}

\section{Article Info \\ Article history: \\ Received Oct 25, 2020 \\ Revised Aug 27, 2021 \\ Accepted Sep 8, 2021}

\section{Keywords:}

Counseling strategy

Poor academic performance

Private university

University students

\begin{abstract}
Poor academic performance is challenging for students, parents, and teachers. This cross-sectional study aimed to determine the factors associated with the poor academic performance of 661 undergraduate students who scored CGPA $\leq 2.5$ from a selected private university of Dhaka City, Bangladesh, using a simple random sampling technique. Data were collected using a pretested and self-administered questionnaire. Of the study participants, male preponderance $(88.4 \%$ ) was found, and $77.9 \%$ of them selected the study programs by themselves. Poor academic performance was found significantly correlated with irregular class attendance $(\mathrm{p}=0.003)$, father's low education level $(\mathrm{p}<0.003)$, partial family cooperation $(\mathrm{p}=0.020)$, use of social media $(\mathrm{p}=0.006)$, and excessive time spent for gossiping $(\mathrm{p}=0.030)$. There is a need for implementing an appropriate counseling strategy to follow up the academic performance of the poor performing students.
\end{abstract}

This is an open access article under the CC BY-SA license.

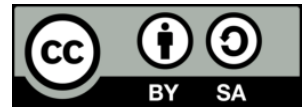

\section{Corresponding Author:}

\author{
M. Shahjahan \\ Department of Public Health \\ Daffodil International University (DIU) \\ Dhaka, Bangladesh \\ Email: mdshahjahan@agnionline.com
}

\section{INTRODUCTION}

Learning is the knowledge or skill acquired through study, which reflects in the way students respond to environmental, social, emotional, and physical incentives as well as understand new information [1]. Academic performance is considered as a complex student's behavior that inspires a number of abilities like memory, previous knowledge or aptitude, as well as psychological factors [2]. Nowadays, in most of the university students' academic performance has become an important issue for researchers [3]. Educators, trainers, and researchers have given emphasize in discovering variables that have a significant contribution to the performance of learners [4]. Academic performance is the assessment of a student's ability in a variety of academic areas. Classroom performance, graduation rates, and standardized test results are commonly used by teachers and education administrators to evaluate student accomplishment.

University life is one of life's most memorable experiences and a vital growth phase for young people [5]. During this university period, many students dedicate most of their time for their studies 
particularly, during examinations yet, their performance is not up to the mark due to stress and other factors [6]. Gender, age, teaching faculty, students' schooling, father/guardian socioeconomic status, residential area of students, medium of instruction in schools, tuition trend, daily study hour, and accommodation as hostelries or day scholars have all been identified as potential factors that affect a student's academic performance in previous studies [7]. Students' academic performances have been studied at different levels by different researchers. According to Graetz, a student's educational progress is significantly influenced by the socioeconomic position of his or her parents/guardians [8]. The study of Considine and Zappala [9] added that the student test score in the examination is influenced by the parent's income and social status. In addition, Bratti and Staffolani [10] observed that a student's future accomplishment largely depends on his/her previous educational outcomes where a greater past appearance indicates that the student will perform better academically in future undertakings.

Academic performance of the students influences a country's social and economic development [11], [12]; as a result, studies focusing on aspects related to academic performance, particularly those emphasizing institutional, psychological, pedagogical, social, and demographic variables for institutional reform, have grown in importance [13]. Several researches have been conducted in numerous universities throughout the world to discover the factors that contribute to poor academic performance. The majority of these research concentrate on the three intervening elements: parents (family causal factors), teachers (academic causal factors), and students (student causal factors) (personal causal factors) [14], [15].

Furthermore, university students are among the most active users of the internet and social media [16]. Nowadays, screen viewings, as well as social media use are considered as one of the most common sedentary activities of the university students. Researchers have found that excessive screen time in young people has significant adverse effects on their wellbeing as well as a negative influence on academic performances that followed into their adulthood [17]-[19]. More than half of teenagers use social media sites more than once a day, and $22 \%$ use them above ten times per day [20].

A very recent study among university students revealed a negative association between poor academic performance and addiction to social networking [16]. Diagnostic investigations must be conducted to assess the primary causes associated with poor academic performance in order to implement corrective actions [21]. The combination of factors that influence academic achievement changes from one academic context to the next, from one group of students to the next, and even from one cultural setting to the next. The importance of identifying and studying variables that can be manipulated or modified by educational institutions is deduced, however, there is an area of opportunity for the study of variables in the pedagogical and institutional areas that could contribute to educational improvement.

In Bangladesh, Daffodil International University (DIU) emerged as one of the prominent Information and Communications Technology (ICT)-based universities. The university is widely recognized for the quality of its Bachelor's and Master's Programs. University Grants Commission (UGC) of Bangladesh recognized this university in the top layer in its ranking of private universities because of its commitment to provide high standard education with all sorts of facilities to the students [22].

Recently, DIU students' academic performance has come under the spotlight because there are over 5000 students with Cumulative Grade Points Average (CGPA) <2.5 in the summer 2016 semester who are the at-risk student to increase their persistence. As a result, a student who obtains a CGPA <2.5 upon completion of the entire course work, could not be graduated smoothly and may be allowed to repeat one-two courses of the lowest grades to improve the CGPA. The importance of these research stems from the necessity to adopt remedial actions to improve students' academic performance, particularly in private institutions. The purpose of this present study was to find out and analyze the factors influencing the academic performance of academically at-risk undergraduate students in the summer semester 2016 of DIU.

\section{RESEARCH METHOD}

\subsection{Survey design and data collection}

The data for the study came from a cross-sectional retrospective survey among the students of DIU. The survey was conducted from September 2016 to December 2016. The study was approved by the University Research Ethics Committee. The targeted population of the study was the at-risk undergraduate students who scored CGPA $\leq 2.5$ in the summer 2016 semester of their academic calendar. In most of the institutions in Bangladesh, the medium of education at the Secondary School Certificate (SSC) and Higher Secondary School Certificate (HSC) level is Bengali, whereas English is the medium of instruction at the university level. Thus, these academically at-risk students may face problems in understanding lectures delivered in English at the university level, which may affect their results at the university. Sample students were selected from five faculties including Allied Health Sciences, Business \& Entrepreneurship, Engineering, Humanities, and Social Science and Science \& Information Technology (IT). Sample students 
were allocated proportionately among the 19 departments. In each of the departments, a simple random sampling (SRS) technique was used to gather information from 661 sampled students. Here, poor performance means attaining lower CGPA $(\leq 2.5$ out of 4.0$)$ in summer semester examinations and refers to being the state of a quality that is low or lower than expected. A self-administered questionnaire was used to collect quantitative data. The semi-structured questionnaire was finalized after pretesting on a small sample of 30 students from one faculty.

In the analysis, many explanatory variables were included, which broadly classified as Sociodemographic characteristic (such as income/expense index, living accommodation, living arrangement of students, number of family members, parent's education and occupation, gender, religion, use of internet with mobile phone/laptop). Student's academic performance such as results in English at SSC and HSC level, participated in DIU Basic English course, class attendance, quiz participation, class presentation, use of the library, regular attendance of examination. The Chi square test was conducted to find association between selected factors (daily study hour, percentage of classes present, regularity using of library, educational level of father, family cooperation, gossiping/hang out with friend, and time spent on social media) and weakness in English.

\subsection{Statistical analysis}

The data was analyzed using the SPSS version 24 in accordance with the study's objectives. Descriptive analysis of all relevant variables was done using measures of central tendency, and dispersion. The statistically significant association (significant level set at $\mathrm{p}$ value $\leq 0.05$ ) was tested by a Chi-square test between the variables weakness in English and selected factors (daily study hour, percentage of classes present, regularity using of library, educational level of father, extended of family contribution, gossiping/hang out with friend, and time spent on social media).

\section{RESULTS}

\subsection{Socio-demographic and educational background}

Table 1 portrays the socioeconomic status of the sampled students. The proportion of female students with a Grade Point Average (GPA) of less than 2.5 was very negligible (11.6\%) compared to their counterparts $(88.4 \%)$. The proportion of mothers and fathers with no formal education or up to primary level education (low education level) were $59.9 \%$ and $46.3 \%$ respectively. The result shows that the average monthly family income was 51,414 Bangladeshi Taka (BDT) which is slightly above the threshold income, 50,000 BDT. Only $17.4 \%$ of the students came from families with a monthly income above 50,000 BDT and the vast majority $(82.6 \%)$ came from the families with monthly income less than 50,000 BDT. The majority of the students $(77.9 \%$ ) choose their study program themselves, yet they performed poorly at the university.

Table 1. Background characteristics of the study subjects $(n=661)$

\begin{tabular}{|c|c|c|}
\hline \multicolumn{2}{|c|}{ Background characteristics } & Number $(\%)$ \\
\hline \multirow[t]{2}{*}{ Gender } & Male & $584(88.4)$ \\
\hline & Female & $77(11.6)$ \\
\hline \multirow[t]{2}{*}{ Parent's living place } & Urban & $350(53.0)$ \\
\hline & Rural & $311(47.0)$ \\
\hline \multirow[t]{3}{*}{ Fathers' education level } & No formal education/Primary & $306(46.3)$ \\
\hline & Secondary/Higher secondary & $281(42.5)$ \\
\hline & Bachelor or above & $74(11.2)$ \\
\hline \multirow[t]{3}{*}{ Mothers' education level } & No formal education/Primary & $396(59.9)$ \\
\hline & Secondary/Higher secondary & $156(23.6)$ \\
\hline & Bachelor or above & $109(16.5)$ \\
\hline \multirow[t]{4}{*}{ Monthly income of the family } & Up to 25,000 & $207(31.3)$ \\
\hline & $25,001-50,000$ & $339(51.3)$ \\
\hline & $>50,000$ & $115(17.4)$ \\
\hline & Mean \pm SD & $51,414 \pm 79,261$ \\
\hline Previous academic performance based on CGPA & 4.00 to $5.00(\mathrm{~A}, \mathrm{~A}+)$ & $573(86.7)$ \\
\hline \multirow[t]{2}{*}{ SSC } & 3.00 to $3.99(\mathrm{~B}, \mathrm{~A}-)$ & $86(13.0)$ \\
\hline & 2.00 to $2.99(\mathrm{C})$ & $2(0.3)$ \\
\hline \multirow[t]{3}{*}{ HSC } & 4.00 to $5.00(\mathrm{~A}, \mathrm{~A}+)$ & $364(55.1)$ \\
\hline & 3.00 to $3.99(\mathrm{~B}, \mathrm{~A}-)$ & $278(42.0)$ \\
\hline & 2.00 to $2.99(\mathrm{C})$ & $19(2.9)$ \\
\hline \multirow[t]{2}{*}{ Independence of choosing current study program } & Self & $515(77.9)$ \\
\hline & Family \& others & $146(22.1)$ \\
\hline
\end{tabular}


Table 2 shows that $68.7 \%$ of students scored GPA 4.0 to $5.0,27.4 \%$ of students scored GPA 3.0 to 3.9, and only $3.9 \%$ of students' GPA score was less than 3.00 in English, respectively, at the SSC level. On the other hand, at the HSC level, 3\% of students scored GPA 4.0 to 5.0, and $42.1 \%$ of students scored GPA 3.0 to 3.9, and only 8.6\% of students' GPA score was less than 3.0 in English, respectively. Furthermore, $57.6 \%$ of the sampled students participated in the Basic English course at DIU. Out of GPA 4.0, only 7.1\% scored below 2.5 and $92.9 \%$ scored above 2.5 , respectively.

Table 2. Academic performance in English according to CGPA of the study subjects

\begin{tabular}{llc}
\hline \multicolumn{1}{c}{ Variable } & & Number (\%) \\
\hline English in SSC examination $(\mathrm{n}=661)$ & 4.00 TO 5.00 (A, A+) & $454(68.7)$ \\
& 3.00 TO 3.99 (B, A-) & $181(27.4)$ \\
& 2.00 TO 2.99 (C) & $26(3.9)$ \\
English in HSC examination $(\mathrm{n}=661)$ & 4.00 TO 5.00 (A, A+) & $326(49.3)$ \\
& 3.00 TO 3.99 (B, A-) & $278(42.1)$ \\
& 2.00 TO 2.99 (C) & $55(8.3)$ \\
Participated in DIU Basic English Course & 1.00 TO 1.99 (D) & $2(0.3)$ \\
during first semester (n=381) & 2.00 TO 4.00 (B to A+) & $282(74.0)$ \\
& 2.49 TO 2.99 (C+ to B-) & $72(18.9)$ \\
& & $27(7.1)$ \\
\hline
\end{tabular}

\subsection{Study environment and cooperation of parents and teachers}

A proper study environment, the cooperation of the parents, and the cooperation of the teachers are pre-requisites for better academic performance by students. The study shows that about three-fourths (71.3\%) of sampled students had a chair/table for study and the rest of them studied either on the bed or on the floor as shown in Table 3. Most of the students $(80.5 \%)$ got partial cooperation from the family regarding their studies.

Regular attendance in class is an important determinant of good academic performance. In this study, $84.4 \%$ of students attended less than $75 \%$ of classes and regular use of the library by the sampled students was disheartening. An immense majority $(73.5 \%)$ of the student did not use the library regularly. Several reasons were mentioned by students for not using the library regularly. A total of $29.6 \%$ of them mentioned the lack of time as a reason. Other reasons were a shortage of books $(23.3 \%)$, insufficient sitting space $(21.2 \%)$, noisy environment $(12.1 \%)$, unfair manner of the staff $(8.6 \%)$ and lack of toilet facility $(5.1 \%)$. Those who used the library regularly spent only six hours per week on average, which was negligible. Among the library non-users $(n=486)$, only $12.1 \%$ reported library environment was unpleasant.

Table 3. Distribution of associated factors with poor academic performance of the study subjects

\begin{tabular}{llc}
\hline & Variables & Number $(\%)$ \\
\hline Logistic at residence & Chair/Table & $471(71.3)$ \\
& On the bed/on the floor & $190(28.7)$ \\
Family cooperation & Partial & $532(80.5)$ \\
& Full & $129(19.5)$ \\
Use library regularly & Yes & $175(26.5)$ \\
& No & $486(73.5)$ \\
If no, reasons for not using (n=486) & Shortage of time & $144(29.6)$ \\
& Shortage of books & $113(23.3)$ \\
& Insufficient space & $103(21.2)$ \\
& Unpleasant environment & $59(12.1)$ \\
& Unfair manner of the staff & $42(8.6)$ \\
Social media time spent (hours/day) & Lack of toilet facility & $25(5.1)$ \\
& $\leq 3$ hours & $236(35.7)$ \\
The average amount of time spent on social media (Mean \pm SD) & $>3$ hours & $425(64.3)$ \\
Gossiping/Hang out with friends per day & & $4.8 \pm 1.6$ \\
& $<2$ hours & $42(6.3)$ \\
Regular attendance in class & $\geq 2$ hours & $619(93.7)$ \\
& $\geq 75 \%$ & $103(15.6)$ \\
Average time spent in study per day (Mean \pm SD) & $<75 \%$ & $558(84.4)$ \\
\hline
\end{tabular}

Social media use makes pursuing higher education easier. A large majority of the students owned a laptop and had access to the internet and all of them use social media (e.g., Facebook, Twitter, Instagram, WhatsApp, and YouTube) regularly. On average, a student time spent in the social media was $4.80 \pm 1.6$ hours 
daily. Access to the internet is becoming a great help to pursue higher education. At the same time, it can be a deterrent to academic performance if it is not used positively. Near about $54 \%$ of the students spent more than two hours for academic study per day and almost all the students (93.7\%) spent excessive time on gossiping with friends.

\subsection{Factors associated with poor academic performance}

Table 4 illustrates the factors determinants for poor academic performance of the students. Irregular class attendance $(p=0.003)$, low education level of the father $(p=0.003)$, partial family cooperation $(p=0.020)$ were significantly associated with the poor academic performance. Similarly, excessive time spent for gossiping with friends $(\mathrm{p}=0.030$ ), and excess use of social media $(\mathrm{p}=0.006)$ were also found to be significantly associated with the students' poor academic performance.

Table 4. Factors associated with poor academic performance among the study subjects

\begin{tabular}{|c|c|c|c|c|}
\hline \multirow{2}{*}{\multicolumn{2}{|c|}{ Factors associated }} & \multicolumn{2}{|c|}{ Weakness in English is the reasons for poor result } & \multirow{2}{*}{$\mathrm{p}$ value } \\
\hline & & Yes n $(\%)$ & No $\mathrm{n}(\%)$ & \\
\hline \multirow[t]{2}{*}{ Daily study hour } & $\leq 2$ hours & $161(52.4)$ & $146(47.6)$ & 0.848 \\
\hline & $>2$ hours & $183(51.7)$ & $171(48.3)$ & \\
\hline \multirow[t]{2}{*}{ Percentage of Classes present } & $\geq 75 \%$ & $40(38.8)$ & $63(61.2)$ & 0.003 \\
\hline & $<75 \%$ & $304(54.5)$ & $254(45.5)$ & \\
\hline \multirow[t]{2}{*}{ Regularity using of Library } & Yes & $90(51.4)$ & $85(48.6)$ & 0.850 \\
\hline & No & $254(52.3)$ & $232(47.7)$ & \\
\hline \multirow[t]{3}{*}{ Educational level of Father } & No formal education/Primary & $140(45.8)$ & $166(54.2)$ & 0.003 \\
\hline & Secondary/Higher secondary & $154(54.8)$ & $127(45.2)$ & \\
\hline & Bachelor or above & $50(68)$ & $24(32)$ & \\
\hline \multirow[t]{2}{*}{ Extended family contribution } & Partial & $265(49.8)$ & $267(50.2)$ & 0.020 \\
\hline & Full & $79(61.2)$ & $50(38.8)$ & \\
\hline \multirow[t]{2}{*}{ Gossiping/Hang out with friend } & $\leq 2$ hours & $31(73.8)$ & $11(26.2)$ & 0.030 \\
\hline & $>2$ hours & $313(50.6)$ & $306(49.4)$ & \\
\hline \multirow[t]{2}{*}{ Time spent on social media } & $\leq 3$ hours & $74(31.4)$ & 162 (68.6) & 0.006 \\
\hline & $>3$ hours & $270(63.5)$ & $155(36.5)$ & \\
\hline
\end{tabular}

\section{DISCUSSION}

The purpose of this study was to investigate the reasons and factors that contributed to DIU students' poor academic performance during the summer semester of 2016. Several studies revealed that student's outcomes and academic performance are significantly influenced by the student's socio-demographic background such as gender [6]. In this study, the proportion of female students with a GPA of less than 2.5 was very negligible compared to their male counterparts $(11.6 \%$ against $88.4 \%)$. It appears that 'gender' played an important role in the academic performance of the DIU students, where female student's academic performance found better than their male counterparts. A similar result was obtained in another study where females performed better than males in every subject though it was performed at the high school level [23]. Another study by Jaeger and Eagan [24] found a significant positive relationship between gender and academic performances of the students. The study shows a common trend of females performing better than in the past. Studies revealed a better memory of female than male, and this comprises all types of memory: episodic, spatial, short-term, visual, and specific memories like odor and early memories [25], [26]. This might help to illuminate why females perform better than males.

Different study [27] reported that family background, parental characteristics, and attributes as well as parental view of the importance of education and what they do in terms of serving and managing their children are all essential factors in a child's academic success in their education system. This study revealed that about half $(47.0 \%)$ of the parents resided in the rural areas and it is logical to assume that their children had a weaker base at pre-university education (school and college level) and were likely to perform low at the university level. The study determined that home location has a significant effect on students' academic performance. Moreover, other studies [28], [29] found that the locality of students' residence is correlated with academic performances. It was also highlighted on the importance, provision and influence of family educational climate that is conducive to learning; hence, no clear conclusion could be made about the influence of parents' area of residence on the students' academic performance. This might be due to the fact that proper weight representing the composition of 'area of residence of parents' in the population could not be used. The intelligence quotient of the parents is positively associated with the student's academic accomplishment [30].

A study conducted in Nigeria revealed that socio-demographic background especially education of the parents, profession and family income as the key predictive variable that affects students' academic 
performance and these finding has already been supported by various studies [27], [31]-[36]. Parents with higher education understand the importance of education and hence try to provide every support including proper guidance to their children. In this study, considering the factors such as fathers' education level and family contribution found significantly correlated with their academic potential and achievement. The study found a significant positive association between poor academic performance of the respondents with their fathers no formal education or primary level education. Hudson [37] and Staats, et al. [38] agree that parent's education has long-term impacts on student educational achievement. A number of studies supported our study findings, where they revealed a significant positive association of parental education with the academic performance of the students [39]-[41].

Family income is another important determinant of academic achievement, particularly studying at a private university, where education is fairly expensive. A number of different studies supported that the socio-economic status is an important determinant of the personal education achievement of the students [42]-[45]. In this study, considering 50,000 BDT as the threshold family income for meeting the educational expenses of a student, it is very likely that as high as $82.6 \%$ of families could not provide adequate financial support and this might be a barrier to the academic performance. The effect of low income on the welfare of the family directly/indirectly may contribute to poor performance when a family is failed to provide a favorable atmosphere for their children. The study determined that family cooperation has a significant influence on the students' academic performance. The study of Hale [46], Goddard [47], and Barnard [48] agreed with this result and they also found that students' academic attainment depends on their parental care and support. Young and Smith [15] stated that the average educational level of parents has been increasing since the 1970s. This is a sign that there is a shift in the family's ability to support and inspire education for their children.

The study found a significant positive association between irregular class attendance and poor academic performance of the students $(\mathrm{p} \leq 0.01)$. Previous findings [49], [50] corroborate the result of this study where they demonstrated students' academic performance is strongly correlated with the consistent class attendance of the students. Students who regularly attend their class perform better than the irregular students in the exam. Our study also revealed that excessive time spent for gossiping with a friend has a significant effect on the students' academic performance. According to Waddington [51], gossiping is an important element in organizational communication. It is considered as a means of social control and considered as a significant stand against the spoiling of group norms [52]. However, gossiping with friends may sometimes be useful or harmful. It may also have a long-term negative impact on a person's selfconfidence and self-esteem and this impact might, in some cases, contribute to the development of depression, anxiety, suicidal thoughts. Research is needed to explore the association between gossiping with friends and academic performance with young people.

The rapid advancement of media technology has a great impact on the way people communicate daily. Most of the studies [53]-[57], conducted on students' use of social media sites and its impact on academic performance focused on students in the developed world. The study revealed that almost all of the students enrolled in this study spend a big amount of time in social media and other networking sites for example 'hangout' for non-academic purposes, which was significantly correlated $(\mathrm{p} \leq 0.01)$ with their low academic performance that may play an important role in their poor academic achievement. This finding is supported by Al-Yafi, El-Masri, and Tsai [58] who found that it is still growing and approximately $85 \%$ of undergraduate students are Facebook users or YouTube users [59] which may have a negative effect on their poor academic performance. A study by Azizi, Soroush, and Khatony [16] determined similar findings where they revealed that uncontrolled use of social networks reduces students' academic performances. In addition, evidence recommends that overuse of social media like Facebook is associated with a significant level of stress which negatively affects the student's academic performance [60].

\section{CONCLUSION}

This study concluded that father's low education level, partial family cooperation, irregular class attendance, excessive time spent for gossiping with friends, and overuse of smart-phone (time spent on social media) significantly influence poor academic performance during the summer semester final examination in 2016. The study revealed empirical evidence that can be useful for decision-making to improve educational procedures in university settings. However, the main challenge was the recruitment and participation rate, which included a small number of students from only one private university, as well as a limited geographic representation of urban students from Dhaka city, Bangladesh. The results may not be transferable to other settings in Bangladesh as more than two-thirds of the total population living in the peri-urban and rural remote communities. Further, this was a cross-sectional study, which cannot find the causal association between the factors and poor academic performances of the students. 
The study recommended that a similar study should be conducted at a wide level of Bangladesh so that its result becomes valid for the whole country. To improve the academic performance of the university students, the university administration should provide more scope of learning to the poor performing students and also improve the environment of the university as this will enhance students' concentration. Proper guidance is very important to improve performance thereby; students should be properly guided by the teacher of the university. Parental involvement and guidance are also very important in improving students' academic performance so they should be well informed about the performance of their daughter/son. University teachers and parents should have well understanding; besides, they should be made aware of their roles in the achievement of their students.

Moreover, the study recommended strengthening family cooperation, increasing regular class attendance, limiting gossiping time, and avoiding the overuse of smart phone of the students. More attractive teaching techniques can be used by the teachers to motivate poor performing students for learning and obtaining a satisfactory score in the examination. Training courses and workshops can be organized for teachers to develop their teaching skills, particularly for the students who got CGPA less than 2.5. Furthermore, implementing an appropriate counseling strategy to continuously follow up the performance processes of the students are needed, which is related to self-esteem building and their interactions with peers to meet the needs.

\section{ACKNOWLEDGEMENTS}

This study is an outcome of the research project supported by the Daffodil International University's Research Grants Centre derived from the University's budget and internal resources to support academic research. The authors would like to thank the Daffodil International University authority for the financial support.

\section{REFERENCES}

[1] R. Gross, Psychology: The Science of Mind and Behaviour. Hachette UK, 2010

[2] I. J. Deary, M. C. Whiteman, J. M. Starr, L. J. Whalley, and H. C. Fox, "The impact of childhood intelligence on later life: following up the Scottish mental surveys of 1932 and 1947," Journal of Personality and Social Psychology, vol. 86, no. 1, pp. 130-147, 2004, doi: 10.1037/0022-3514.86.1.130.

[3] D. D. S. Tilley, "Competency in nursing: A concept analysis," The Journal of Continuing Education in Nursing, vol. 39, no. 2, pp. 58-64, 2008, doi: 10.3928/00220124-20080201-12.

[4] F. Alshammari, R. Saguban, E. Pasay-an, A. Altheban, and L. Al-Shammari "Factors affecting the academic performance of student nurses: A cross-sectional study," Journal of Nursing Education and Practice, vol. 8, no. 1, pp. 60, 2017, doi: 10.5430/jnep.v8n1p60.

[5] A. W Chickering, Education and identity. San Francisco: Jossey-Bass, 1969.

[6] S. O. Olatunji, D. O. Aghimien, A. E. Oke, and E. Olushola, "Factors Affecting Performance of Undergraduate Students in Construction Related Disciplines," Journal of Education and Practice, vol. 7, no. 13, pp. 55-62, 2016. [Online]. Available: https://eric.ed.gov/?id=EJ1102825.

[7] S. Ali, Z. Haider, F. Munir, H. Khan, and A. Ahmed "Factors contributing to the students academic performance: A case study of Islamia University Sub-Campus," American Journal of Educational Research, vol. 1, no. 8, pp. 283-289, 2013, doi: 10.12691/education-1-8-3.

[8] B. Graetz, "Socio-economic status in education research and policy 'in John Ainley et al., Socio-economic Status and School Education DEET/ACER Canberra,” Journal of Pediatric Psychology, vol. 20, no. 2, pp. 205-216, 1995.

[9] G. Considine and G. Zappalà, "The influence of social and economic disadvantage in the academic performance of school students in Australia," Journal of Sociology, vol. 38, no. 2, pp. 129-148, 2002, doi: $10.1177 / 144078302128756543$.

[10] M. Bratti and S. Staffolani, "Student time allocation and educational production functions," Annals of Economics and Statistics, no. 111/112, pp. 103-140, 2013, doi: 10.2307/23646328.

[11] N. Ali, K. Jusof, S. Ali, N. Mokhtar, and A. S. A. Salamat "The factors influencing students' performance at Universiti Teknologi MARA Kedah, Malaysia," Management Science and Engineering, vol. 3, no. 4, pp. 81-90, 2009, doi: 10.3968/j.mse.1913035X20090304.010.

[12] O. Olusola, S. Taofeek, and O. Olumide, "Parents and Students Interest as Determinants of Students' Academic Performance in Agricultural Science in selected Secondary Schools in Oyo Metropolis, Oyo State," International Journal of Academic Research in Progressive Education and Development, Vol. 4, No. 4, pp. 11-20, 2015, doi: 10.6007/IJARPED/v4-i4/1864.

[13] V. Aramburo, B. Boroel, and G. Pineda, "Predictive factors associated with academic performance in college students," Procedia-Social and Behavioral Sciences, vol. 237, pp. 945-949, Feb. 2017, doi: 10.1016/j.sbspro.2017.02.133.

[14] A. Diaz, "Personal, family, and academic factors affecting low achievement in secondary school," Electronic Journal of Research in Educational Psychology, vol. 1, no. 1, pp. 43-66, 2003. 
[15] B. A. Young and T. M. Smith, "The social context of education. Findings from The Condition of Education," Report, U.S. Department of Education, 1997. [Online]. Available: https://eric.ed.gov/?id=ED413396.

[16] S. M. Azizi, A. Soroush, and A. Khatony "The relationship between social networking addiction and academic performance in Iranian students of medical sciences: a cross-sectional study," BMC Psychology, vol. 7, no. 28, 2019, doi: 10.1186/s40359-019-0305-0.

[17] A. S. Page, A. R. Cooper, P. Griew, and R. Jago "Children's screen viewing is related to psychological difficulties irrespective of physical activity," Pediatrics, vol. 126, no. 5, pp. e1011-e1017, 2010, doi: 10.1542/peds.2010-1154.

[18] K. M. Keyes, J. Maslowsky, A. Hamilton, and J. Schulenberg "The great sleep recession: changes in sleep duration among US adolescents, 1991-2012," Pediatrics, vol. 135, no. 3, pp. 460-468, 2015, doi: 10.1542/peds.2014-2707.

[19] M. M. Aguilar, F. A. Vergara, E. J. A. Velásquez, R. Marina, and A. García-Hermoso, "Screen time impairs the relationship between physical fitness and academic attainment in children," Journal of Pediatrics, vol. 91, no. 4, pp. 339-345, 2015, doi: 10.1016/j.jped.2014.10.004

[20] G. S. O'Keeffe and Clarke-Pearson, "The impact of social media on children, adolescents, and families," Pediatrics, vol. 127, no. 4, pp. 800-804, 2011, doi: 10.1542/peds.2011-0054.

[21] V. Mlambo, "An analysis of some factors affecting student academic performance in an introductory biochemistry course at the University of the West Indies," The Caribbean Teaching Scholar, vol. 1, no. 2, pp. 75-88, 2011.

[22] Daffodil International University (DIU), "Why DIU Stands Out-Daffodil International University," 2020. [Online]. Available: https://daffodilvarsity.edu.bd/article/diu-best\#

[23] O. J. Sparks-Wallace, "A Study of Gender Differences in Academic Performance in a Rural County in Tennessee," Electronic Theses and Dissertations, East Tennessee State University, 2007. [Online]. Available: https://dc.etsu.edu/etd/2101.

[24] A. J. Jaeger and M. K. Eagan, "Exploring the value of emotional intelligence: A means to improve academic performance," NASPA Journal, vol. 44, no. 3, pp. 512-537, 2007.

[25] M. Eals and I. Silverman, "The hunter-gatherer theory of spatial sex differences: Proximate factors mediating the female advantage in recall of object arrays," Ethology and Sociobiology, vol. 15, no. 2, pp. 95-105, 1994, doi: 10.1016/0162-3095(94)90020-5.

[26] D. F. Halpern, Sex differences in cognitive abilities, 4th ed. New York and Hove: Psychology Press, 2000.

[27] J. McIntosh, "Family background parental involvement and academic achievement in Canadian schools," 2007. [Online]. Available: https://studylib.net/doc/10820387/family-background--parental-involvement--and-academicach.

[28] M. Ogbemudia and M. Aiasa "Influence of home environment on the academic performance of primary five pupils' in English Language in Orhionmwon Local Government Area of Edo State," Merit Research Journal of Education and Review, vol. 1, no. 5, pp. 120-125, 2013.

[29] T. Tuttle, "Family Background, Locality, and the Influence on SAT Scores for Indiana Class of 2000," Hoosier Briefs, no. 2, 2004. [Online]. Available: http://citeseerx.ist.psu.edu/viewdoc/summary?doi=10.1.1.498.7830.

[30] H. Coon, G. Careya, D. W. Fulker, and J.C. DeFries, "Influences of school environment on the academic achievement scores of adopted and nonadopted children," Intelligence, vol. 17, no. 1, pp. 79-104, 1993, doi: 10.1016/0160-2896(93)90040-C.

[31] I. Altschul, "Linking socioeconomic status to the academic achievement of Mexican American youth through parent involvement in education," Journal of the Society for Social Work and Research, vol. 3, no. 1, pp. 13-30, 2012, doi: 10.5243/jsswr.2012.2.

[32] L. A. Udida, J. K. Ukwayi, and F. A. Ogodo, "Parental Socioeconomic Background as a Determinant of Student's Academic Performance in Selected Public Secondary Schools in Calabar Municipal Local Government Area, Cross River State, Nigeria," Journal of Education and Practice, vol. 3, no. 16, pp. 129-135, 2012. [Online]. Available: https://www.iiste.org/Journals/index.php/JEP/article/view/3705/3754.

[33] R. Castillo, et al., "Associations between parental educational/occupational levels and cognitive performance in Spanish adolescents: The AVENA study," Psicothema, vol. 23, no. 3, pp. 349-355, 2011. https://pubmed.ncbi.nlm.nih.gov/21774884.

[34] M.S. Farooq, A.H. Chaudhry, M. Shafiq, and G. Berhanu, "Factors affecting students' quality of academic performance: a case of secondary school level," Journal of Quality and Technology Management, vol. 7, no. 2, pp. 1-14, 2011.

[35] Q. Suleman, I. Hussain, and Z. Nisa "Effects of Parental Socioeconomic Status on the Academic Achievement of Secondary School Students in Karak District (Pakistan)," International Journal of Human Resource Studies, vol. 2, no. 4, pp. 14-32, 2012, doi: 10.5296/ijhrs.v2i4.2511.

[36] C.D. Wu, et al., "Linking student performance in Massachusetts elementary schools with the 'greenness' of school surroundings using remote sensing," PloS One, vol. 9, no. 10. 2014, doi: 10.1371/journal.pone.0108548.

[37] J.B. Hudson, "The long-term performance and retention of preparatory division transfer students: 1983-1990" ERIC, Document Reproduction Services, 1991. [Online]. Available: https://eric.ed.gov/?id=ED334918.

[38] S. Staats, R. Butler, C. Partlo, and K. Heaphey, "Intent to get a degree, expectations, and attitude change," Dayton, OH: Wright State University, 1991. [Online]. Available: https://files.eric.ed.gov/fulltext/ED344525.pdf.

[39] M. Azhar, S. Nadeem, F. Naz, F. Perveen, and A. Sameen, "Impact of parental education and socio-economic achievement of university students," European Journal of Psychological Research, vol. 1, no. 1, pp. 1-9, 2014. [Online]. Available: https://www.idpublications.org/wp-content/uploads/2014/11/IMPACT.pdf.

[40] E. Tomul and P. Gokhan, "The effects of socioeconomic characteristics of students on their academic achievement in high education," American Journal of Educational Research, vol. 1, no. 10, pp. 449-455, 2013. 
[41] T. P. Ghuntta, B. M. Hemant, A. G. Pradnya, and J. S. Chinmay, "A study of socio-economic and parental educational background of first year medical student in medical college behaviour," International Research Journal of Pharmacy, vol. 3, no. 9, pp. 253-255, 2012. [Online]. Available: http://www.irjponline.com/admin/php/uploads/1392_pdf.pdf.

[42] C. Li, "Expansion of higher education and inequality in opportunity of education: A study on effect of 'kuozhao' Policy on equalization of educational attainment," Sociological Studies, vol. 3, pp. 82-113, 2010. [Online]. Available: https://en.cnki.com.cn/Article_en/CJFDTOTAL-SHXJ201003004.htm.

[43] J. Golley and S. T. Kong, "Inequality of opportunity in China's educational outcomes," China Economic Review, vol. 51, pp. 116-128, 2018, doi: 10.1016/j.chieco.2016.07.002.

[44] X. Wu, "Economic transition, school expansion and educational inequality in China, 1990-2000," Research in Social Stratification and Mobility, vol. 28, no. 1, pp. 91-108, 2010, doi: 10.1016/j.rssm.2009.12.003.

[45] L. Zhonglu, "Family background, academic performance and admission to postgraduate study in China," Chinese Journal of Sociology, vol. 3, no. 4, 2016. [Online]. Available: http://en.cnki.com.cn/Article_en/CJFDTotalSHEH201603004.htm.

[46] J. Hale, Learning while black: Creating educational excellence for African American children. Baltimore: The John Hopkins University Press, 2001.

[47] R. D. Goddard, "Relational networks, social trust, and norms: A social capital perspective on students' chances of academic success," Journal of Educational Evaluations \& Policy Analysis, vol. 25, no. 7, pp. 59-74, 2003.

[48] W. M. Barnard, "Parent involvement in elementary school and educational attainment," Children and Youth Services Review, vol. 6, no. 26, pp. 39-62, 2004.

[49] V. Kassarnig, A. Bjerre-Nielsen, E. Mones, S. Lehmann, and D. D. Lassen "Class attendance, peer similarity, and academic performance in a large field study," PloS One, vol. 12, no. 11, 2017.

[50] A. Kirby and McElroy, "The Effect of Attendance on Grade for First Year Economics Students in University college Cork," The Economic and Social Review, vol. 34, no. 3, pp. 311-326, 2003.

[51] K. Waddington, "Using diaries to explore the characteristics of work-related gossip: Methodological considerations from exploratory multimethod research," Journal of Occupational and Organizational Psychology, vol. 78, no. 2, pp. 221-236, 2005.

[52] K. M. Kniffin and D. S. Wilson, "Utilities of gossip across organizational levels," Human Nature, vol. 16, no. 3, pp. 278-292, 2005.

[53] S. Mehmood and T. Taswir, "The effects of social networking sites on the academic performance of students in college of applied sciences, Nizwa, Oman," International Journal of Arts and Commerce, vol. 2, no. 1, pp. 111$125,2013$.

[54] N. Upadhayay and S. Guragain, "Internet use and its addiction level in medical students," Advances in Medical Education and Practice, vol. 8, pp. 641-647 2017, doi: 10.2147/amep.s142199.

[55] R. W. Kubey, M. J. Lavin, and J. R. Barrows "Internet use and collegiate academic performance decrements: Early findings," Journal of Communication, vol. 51, no. 2, pp. 366-382, 2001, doi: 10.1111/j.1460-2466.2001.tb02885.x.

[56] R. S. Miguel, "Study on Facebook and grades becomes learning experience for researcher," Tech News World, 2009. [Online]. Available: http://www.technewsworld.com/rsstory/66805.html.

[57] M. Owusu-Acheaw and A. G. Larson, "Use of Social Media and Its Impact on Academic Performance of Tertiary Institution Students: A Study of Students of Koforidua Polytechnic, Ghana," Journal of Education and Practice, vol. 6, no. 6, pp. 94-101, 2015. [Online]. Available: https://eric.ed.gov/?id=EJ1083595.

[58] K. Al-Yafi, M. El-Masri, and R. Tsai, "The effects of using social network sites on academic performance: the case of Qatar," J Enterp Inf Manag., vol. 31, no. 3, pp. 446-462, 2018, doi: 10.1108/JEIM-08-2017-0118.

[59] S. Y. Kim, M.-S. Kim, B. Park, J.-H. Kim, and H. G. Choi, "The associations between internet use time and school performance among Korean adolescents differ according to the purpose of internet use," PLoS One, vol. 12, no. 4, 2017, doi: 10.1371/journal.pone.0174878.

[60] H. Gabre and G. Kumar, "The effects of perceived stress and Facebook on accounting students' academic performance," Accounting and Finance Research, vol. 1, no. 2, pp. 87-100, 2012. 